\title{
Crop production growth in different agro-ecological zones of Bangladesh
}

\author{
M. A. Quddus \\ Department of Agricultural Statistics, Bangladesh Agricultural University, Mymensingh-2202, Bangladesh
}

\begin{abstract}
The purpose of this study is to evaluate the progress and regional variations of crop production in Bangladesh. The secondary data were used and collected for the years 1980-81 to 2002-03 from the 'Statistical Yearbooks of Bangladesh', 'Yearbook of Agricultural Statistics' and population census of different years. The study was conducted during the period from September 2006 to February 2008. An analysis was done for twelve mutually exclusive agroecological zones by assigning various indicators of crop sector development. The remarkable progress of rural literacy rate, ratio of agricultural workers to population, number of farmer's co-operative societies and per capita regional domestic agricultural products in two decades was observed in different regions. Wide disparities in the level of crop sector development had been observed across the regions. The overall results reveal that some of the regions are in better positions in respect of socioeconomic progress, land use pattern, input use, growth performance of HYV rice and food-grains production. The developed regions were 'Old Himalayan Piedmont Plain and Tista Floodplain', 'Karatoya Floodplain and Atrai Basin', 'Brahmaputra-Jamuna Floodplain' and 'Middle Meghna River Floodplain' on the basis of land utilization pattern, input use and food-grains production. Analysis of regional disparities reveals that 'Sylhet Basin and Surma-Kusiyara Floodplain', Greater Dhaka', 'Middle Meghna River Floodplain' and 'Lower Meghna River and Estuarine Floodplain' regions has developed remarkably in the last twenty years.
\end{abstract}

Keywords: Crop production, Development indicator, Growth performance, Regional variation

\section{Introduction}

The overall agricultural development in Bangladesh conceals considerable regional differences because of farming practices, techniques, availability of irrigation facilities, attitude of the farmer etc. in different parts of the country. The differences in agricultural productivity among the regions to some natural phenomena, such as, rainfall, temperature, humidity and some other agro-ecological features which are relatively less favourable in the lagging regions. It is not only the natural phenomenon but also government policies in the past relating to agricultural extension, input distribution, institutional credit facilities, agricultural co-operatives, and some basic/institutional inefficiency are the causes of backwardness in productivity in the lagging regions. Productivity differences also may due to the government policies in allocating subsidized inputs such as chemical fertilizers, irrigated water, high yielding varieties of seeds, pesticides etc. The agricultural extension facilities of a productive region may cause to deprive the lagging regions to some extent.

Regional variations in agricultural development show that there is scope to boost up the pace of agricultural development and thereby that of economic development in the country with area specific agricultural development programmes and policies (Singh, 1990). The poor economy of the country cannot afford to contend with low rate of crop yields in view of heavy pressure of population on agriculture. There is obviously high degree of inequality in the distribution of land and small and marginal holdings constitute most of the operated area. Net cultivated area per farm household was decreased from 1.23 ha in 1977 to 0.61 ha in 1996 (BBS, 1996). The annual rate of increase of total cereal production between $1990-91$ and 1998-99 was only 1.43 percent (Quddus et al. 2004).

It would be of interest to measure the level of agricultural development at regional level and this knowledge can serve as a useful preliminary guide to measure economic development of the country. The relative level of development of crop sector of a region will help to balance the major agro-ecological regions in Bangladesh as a development strategy. Keeping these in view, a detailed study was undertaken i) to know the increase of agricultural workers and improvement of agricultural economy in different regions; ii) to evaluate the improvement of land utilization pattern and input use across the regions; iii) to determine the growth performance of HYV rice and food-grains production in different agroecological zones and iv) to measure regional disparities based on development indicators of crop production. 


\section{Materials and Methods}

Time series data of different crops, area irrigated, fertilizer used etc. were collected mainly by district and then aggregated them according to the twelve combined agro-ecological regions. Secondary data were collected from different published sources. The main sources were the Statistical Yearbook of Bangladesh of different years, Yearbook of Agricultural Statistics of Bangladesh of different years, Population Census, 1981 and 2001, Agricultural Sample Survey of Bangladesh - 2005 and data base of Ministry of Agriculture (MOA), 2005.

The regional variations were analysed by considering a stable regional base of homogeneous agroecological zones. Such zonations scheme would provide a base to explain the effects of agro-ecological conditions as well as agricultural development. Agricultural, especially, district wise crop data are available. Bangladesh consists of 30 agro-ecological zones (AEZ) those are overlapping with each other. For convenience of the study, two to three AEZs were combined for a region. A total number of 12 mutually exclusive regions were considered for the study. Their characteristics followed the characteristics of the AEZs. Each region was the aggregate of a number of administrative districts. Each of the regions was not equally endowed by the nature with their geographical areas. The names of the regions with included districts and their nature are shown in Table 1.

Table 1. Name of the regions and their characteristic features

\begin{tabular}{|c|c|c|c|c|c|c|}
\hline $\begin{array}{c}\text { Symbol of } \\
\text { Region }\end{array}$ & Name of Region & $\begin{array}{l}\text { District included in } \\
\text { the region }\end{array}$ & $\begin{array}{l}\text { AEZ } \\
\text { covered in } \\
\text { the region }\end{array}$ & $\begin{array}{l}\text { Population (mil) } \\
\text { Area (000sqkm) }\end{array}$ & $\begin{array}{l}\text { Land type } \\
\text { Soil type }\end{array}$ & $\begin{array}{l}\text { Fertility conditions } \\
\text { Organic material }\end{array}$ \\
\hline 1 & 2 & 3 & 4 & 5 & 6 & 7 \\
\hline HPTF & $\begin{array}{l}\text { Old Himalayan Piedmont } \\
\text { Plain and Tista Floodplain }\end{array}$ & $\begin{array}{l}\text { Dinajpur, Panchagar, } \\
\text { Thakurgaon, Rangpur, } \\
\text { Gaibandah, Nilphamari, } \\
\text { Kurigram, Lalmonirhat }\end{array}$ & $\begin{array}{l}\text { AEZ 1, 2, 3, } \\
27\end{array}$ & $\begin{array}{l}13.8 \\
16.3\end{array}$ & $\begin{array}{l}\text { High and medium high } \\
\text { Sandy loam, loamy, } \\
\text { Silt clay-loam }\end{array}$ & $\begin{array}{l}\text { Low to medium } \\
\text { Low / good }\end{array}$ \\
\hline KFAB & $\begin{array}{l}\text { Karatoya Floodplain } \\
\text { And Atrai Basin }\end{array}$ & $\begin{array}{l}\text { Rajshahi, Nawabgonj, } \\
\text { Naogaon, Natore, Bogra, } \\
\text { Joypurhat }\end{array}$ & $\begin{array}{l}\text { AEZ 4, 5, 6, } \\
26\end{array}$ & $\begin{array}{l}11.5 \\
13.3\end{array}$ & $\begin{array}{l}\text { Medium low } \\
\text { Grey, silt loam and silt clay- } \\
\text { loam }\end{array}$ & $\begin{array}{l}\text { Moderate and medium } \\
\text { Medium, low-medium }\end{array}$ \\
\hline BJF & $\begin{array}{l}\text { Brahmaputra- Jamuna } \\
\text { Floodplain }\end{array}$ & $\begin{array}{l}\text { Jamalpur, Sherpur,Tangail } \\
\text { Mymensingh, Kishoregonj, } \\
\text { Netrakona }\end{array}$ & $\begin{array}{l}\text { AEZ } 7,8,9, \\
\text { Part of } 28\end{array}$ & $\begin{array}{l}14.9 \\
16.7 \\
\end{array}$ & $\begin{array}{l}\text { High, medium high, medium } \\
\text { Silt loam to silt clay-loam }\end{array}$ & $\begin{array}{l}\text { Low to medium } \\
\text { Low }\end{array}$ \\
\hline HGRF & $\begin{array}{l}\text { High Ganges River } \\
\text { Floodplain }\end{array}$ & $\begin{array}{l}\text { Pabna Sirajgonj, Jessore, } \\
\text { Jhenaidah, Magura, Narail, } \\
\text { Kustia, Meherpur Chuadanga }\end{array}$ & $\begin{array}{l}\text { Major part of } \\
\text { AEZ 11, } 14\end{array}$ & $\begin{array}{r}13.7 \\
14.8 \\
\end{array}$ & $\begin{array}{l}\text { High, medium high } \\
\text { Silt loam, Silt clay-loam, }\end{array}$ & $\begin{array}{l}\text { Low } \\
\text { Low }\end{array}$ \\
\hline LGRF & $\begin{array}{l}\text { Low Ganges River } \\
\text { Floodplain }\end{array}$ & $\begin{array}{l}\text { Faridpur, Rajbari, Gopalgonj } \\
\text { Madharipur, Shariatpur }\end{array}$ & $\begin{array}{l}\text { Major part of } \\
\text { AEZ 12, } \\
14\end{array}$ & $\begin{array}{l}6.0 \\
7.0 \\
\end{array}$ & $\begin{array}{l}\text { Medium high, medium low } \\
\text { Silt loam, Silt clay-loam }\end{array}$ & $\begin{array}{l}\text { Medium } \\
\text { Medium }\end{array}$ \\
\hline GTF & $\begin{array}{l}\text { Ganges Tidal } \\
\text { Floodplain }\end{array}$ & $\begin{array}{l}\text { Barisal, Bhola, Jhalkati, } \\
\text { Pirojpur, Barguna,Patuakhali } \\
\text { Khulna Bagerhat Satkhira } \\
\end{array}$ & AEZ 13 & $\begin{array}{r}13.9 \\
25.5 \\
\end{array}$ & $\begin{array}{l}\text { Medium low, low } \\
\text { Heavy silt clays, alkaline }\end{array}$ & $\begin{array}{l}\text { Medium to high } \\
\text { Medium }\end{array}$ \\
\hline SBSKF & $\begin{array}{l}\text { Sylhet Basin and Surma- } \\
\text { Kusiyara Floodplain }\end{array}$ & $\begin{array}{l}\text { Sylhet, Sunamgonj, Moulavi } \\
\text { Bazar, Habigonj }\end{array}$ & $\begin{array}{l}\text { AEZ 20, } 21 \\
22\end{array}$ & $\begin{array}{c}7.9 \\
12.6\end{array}$ & $\begin{array}{l}\text { Medium low, low, very low } \\
\text { Heavy silt clay loam, Grey } \\
\text { colour }\end{array}$ & $\begin{array}{l}\text { Low to medium } \\
\text { Medium, High }\end{array}$ \\
\hline MMRF & $\begin{array}{l}\text { Middle Meghna River } \\
\text { Floodplain }\end{array}$ & $\begin{array}{l}\text { Comilla, Chandpur, } \\
\text { Brahmanbaria }\end{array}$ & $\begin{array}{l}\text { AEZ 16, } 30 \\
\text { Minor part of } \\
17,19,22 \\
\end{array}$ & $\begin{array}{l}9.2 \\
6.7 \\
\end{array}$ & $\begin{array}{l}\text { Medium low, low, very low } \\
\text { Grey, Loam, Dark Grey loamy }\end{array}$ & $\begin{array}{l}\text { Medium } \\
\text { Low, Medium } \\
\end{array}$ \\
\hline LMREF & $\begin{array}{l}\text { Lower Meghna River and } \\
\text { Estuarine Floodplain }\end{array}$ & $\begin{array}{l}\text { Noakhali, } \\
\text { Feni, Lakshmipur }\end{array}$ & $\begin{array}{l}\text { Major part of } \\
\text { AEZ 17, 18, } \\
19\end{array}$ & $\begin{array}{l}5.3 \\
6.0 \\
\end{array}$ & $\begin{array}{l}\text { Medium, high-,medium, low } \\
\text { Silt loam, silt clay }\end{array}$ & $\begin{array}{l}\text { Medium } \\
\text { Medium }\end{array}$ \\
\hline CCPSI & $\begin{array}{l}\text { Chittagong Coastal Plain \& } \\
\text { St. Martin's Coral Island }\end{array}$ & Chittagong, Cox's Bazar & AEZ 23, 24 & $\begin{array}{l}8.3 \\
7.8 \\
\end{array}$ & $\begin{array}{l}\text { High, medium high, medium } \\
\text { low } \\
\text { Grey silt loam, Silt clay loam }\end{array}$ & $\begin{array}{l}\text { Medium and low } \\
\text { Low to moderate low }\end{array}$ \\
\hline $\mathrm{EH}$ & Eastern Hills & $\begin{array}{l}\text { Bandarban, Rangamati, } \\
\text { Khagrachhari }\end{array}$ & $\begin{array}{l}\text { Part of AEZ } \\
29\end{array}$ & $\begin{array}{r}1.3 \\
13.3 \\
\end{array}$ & $\begin{array}{l}\text { High } \\
\text { Yellow brown to strong brown }\end{array}$ & $\begin{array}{l}\text { Low } \\
\text { High }\end{array}$ \\
\hline DHAKA & Grater Dhaka & $\begin{array}{l}\text { Dhaka, Gazipur, Manikgonj, } \\
\text { Munshigonj, Narayangonj, } \\
\text { Narshingdi }\end{array}$ & $\begin{array}{l}\text { AEZ } 15 \\
\text { Part of } 7,8 \\
28\end{array}$ & $\begin{array}{l}17.3 \\
7.4 \\
\end{array}$ & $\begin{array}{l}\text { Low-lying, upland, alluvial } \\
\text { Dark Grey, silt loam, clay loam }\end{array}$ & $\begin{array}{l}\text { Low, medium, high } \\
\text { Low and moderate }\end{array}$ \\
\hline
\end{tabular}


In order to calculate the value of most of the development indicators two points of time, the early 1980s (three years average of 1980-81, 1981-82 and 1982-83) and the early 2000s (three years average of 2000-01, 2001-02 and 2002-03) were taken. But three years data were not available for a few indicators and hence only the data of base year was used for these particular indicators. The choice of indicators inevitably depends upon the purpose and the availability of data. For computing growth rates of high yield rice area, production, yield and area irrigated an exponential function of the following form was fitted to the data.

$$
Y=a e^{b t}
$$

Where $b$ is the growth rate and $t$ is the time in year.

To check the significance of the difference between two time periods, paired t-test was employed (Ahmed et al., 2004). The null hypothesis, $\left(\mathrm{H}_{0}\right.$ : Equal production or yield was obtained in both the periods) was tested.

A group of seven indicators directly relating to development of crop production were selected to examine the variations among the twelve regions. All the indicators relate to adoption of modern technology and the government played an active role in promoting this technology. Following indicators together would significantly improve the crop sector as a whole: 'Percentage of net cropped area to total geographic area' (NCAGA), 'Cropping intensity' in percent $(\mathrm{Cl})$, 'Area under HYVs as a percentage of total cropped area' (AHYGCA), 'Area irrigated to total cropped area' in percent (AIGCA), 'Consumption of chemical fertilizer' in kg/ha (FCKH), 'Food-grain productivity' in metric ton/ 100 ha (FPMT) and 'Net cultivated area per 100 agriculture workers' in ha (NCAAW). The disparity among the regions was measured by computing mean value and coefficient of variation of seven indicators for each of the regions.

\section{Results and Discussion}

There are some population characteristics that might have played a vital role in the regional variations in the agricultural development. Population density and literacy rates are the important ones and both of them increased significantly during the period of last two decades. Table 2 reveals that the density of population was highest in Dhaka and the second highest in 'Middle Meghna River Floodplain'. The density of population was lowest in Chittagong Hill Tracts followed by Sylhet basin and coastal regions because they were lagging regions. As for literacy rate the region 'Brahmaputra-Jamuna Floodplain' was the most lagging region during both the period 1980-81 and 2000-01. The coastal and the hill tracts regions occupied the top ranks, especially, in 1980-81 but literacy rate could not help in agricultural development very much because of lagging region. Rural literacy rate also is an indicator of agricultural development and it increased significantly in the period of last two decades (Table 2). Coastal region was the best region as a rural literacy rate followed by the 'Lower Meghna River and Estuarine Floodplain' and 'Greater Dhaka'. The ecological constraints, those lie in these regions might be a factor for the variations in agricultural development. Rural literacy rate had increased remarkably in 2000-01 compared with 198081 for all the regions. The highest increment (23.6\% in 20 years) in 'Greater Dhaka' because of capital city is situated in this region and hence there had enough scope of rural education. The lowest increment (15.2\% in 20 years) was observed in 'Chittagong Hill Tracts' because of very lagging region. Further social value and education might be less emphasized in this region compared to other regions.

Ratio of agricultural workers to population had also increased remarkably in 2004-05 compared with 1980-81 for all the regions (Table 2). This increment was much higher in North Bengal, Faridpur and Chittagong Hill Tracts because of low labour cost due to no other source of employment and modern input use. Highly significant increase of ratio of agricultural workers in two decades indicates that rural people are more involved in agriculture production and it is an important indicator of agricultural development. 'Chittagong Coastal Plain and Martin's Coral Island' and 'Greater Dhaka' regions showed very low increment of ratio of agricultural workers to population due to vast increment of population. Number of farmer's cooperative society per 1000 square kilometer varied in different regions in both the periods. This number was increased in 'Brahmaputra- Jamuna Floodplain', 'Old Himalayan Piedmont Plain and Tista Floodplain' and 'Low Ganges River Floodplain' whereas the number decreased in 'Chittagong Coastal Plain and St. Martin's Coral Island' over the periods of last two decades. Overall increment of this number was highly significant (Table 3). 
Table 2. Changes of some vital population characteristics related to agricultural development in different regions

\begin{tabular}{|c|c|c|c|c|c|c|c|c|c|c|c|c|}
\hline \multirow[t]{2}{*}{ Regions } & \multicolumn{3}{|c|}{ Density of population } & \multicolumn{3}{|c|}{ Literacy rate (\%) } & \multicolumn{3}{|c|}{ Rural literacy rate (\%) } & \multicolumn{3}{|c|}{$\begin{array}{l}\text { Ratio of Agricultural workers to } \\
\text { population (\%) }\end{array}$} \\
\hline & $\begin{array}{c}1980- \\
81\end{array}$ & $2000-01$ & \begin{tabular}{|c|} 
Change in \\
20 years \\
$(\%)$
\end{tabular} & $2000-01$ & $\begin{array}{c}1980- \\
81\end{array}$ & $\begin{array}{c}\text { Change } \\
\text { in } 20 \\
\text { years (\%) }\end{array}$ & $\begin{array}{c}1980- \\
81\end{array}$ & $\begin{array}{c}2000- \\
01\end{array}$ & $\begin{array}{c}\text { Change in } \\
20 \text { years } \\
(\%)\end{array}$ & $1980-81$ & $2004-05$ & $\begin{array}{c}\text { Change in } \\
20 \text { years } \\
(\%)\end{array}$ \\
\hline HPTF & 601 & 844 & 40.4 & 19.2 & 69.8 & 50.6 & 17.3 & 37.2 & 19.9 & 22.4 & 34.5 & 12.1 \\
\hline KFAB & 599 & 861 & 43.7 & 21.4 & 42.8 & 21.4 & 19.5 & 40.1 & 20.6 & 19.6 & 36.9 & 17.3 \\
\hline BJF & 698 & 896 & 28.4 & 17.5 & 37.2 & 19.7 & 16.5 & 33.0 & 16.5 & 21.2 & 31.2 & 10.0 \\
\hline HGRF & 660 & 919 & 39.2 & 20.4 & 43.1 & 22.7 & 17.8 & 40.7 & 22.9 & 18.7 & 29.9 & 11.2 \\
\hline LGRF & 692 & 864 & 24.9 & 21.3 & 42.0 & 20.7 & 20.0 & 40.0 & 20.0 & 19.8 & 35.6 & 15.8 \\
\hline GTF & 460 & 544 & 18.3 & 32.2 & 54.8 & 22.6 & 29.8 & 49.9 & 20.1 & 16.4 & 27.1 & 10.7 \\
\hline SBSKF & 445 & 627 & 40.9 & 19.9 & 45.0 & 25.1 & 18.1 & 36.1 & 18.0 & 19.9 & 26.4 & 6.5 \\
\hline MMRF & 1043 & 1371 & 31.4 & 23.7 & 44.1 & 20.4 & 22.2 & 42.6 & 20.4 & 18.8 & 22.3 & 3.5 \\
\hline LMREF & 699 & 879 & 25.8 & 26.5 & 44.3 & 17.8 & 25.5 & 47.8 & 22.3 & 14.1 & 24.6 & 10.5 \\
\hline CCPSI & 736 & 1068 & 45.1 & 27.9 & 49.4 & 21.5 & 23.6 & 42.1 & 18.5 & 10.6 & 12.2 & 1.6 \\
\hline $\mathrm{EH}$ & 57 & 101 & 77.2 & 21.5 & 48.1 & 26.6 & 15.6 & 30.8 & 15.2 & 23.1 & 36.8 & 13.7 \\
\hline DHAKA & 134 & 2326 & 73.5 & 31.3 & 56.5 & 25.2 & 21.2 & 44.8 & 23.6 & 11.2 & 12.2 & 1.0 \\
\hline Total & 605 & 839 & 38.7 & 23.8 & 45.3 & 21.5 & 17.3 & 37.2 & 19.9 & 17.9 & 26.4 & 8.5 \\
\hline $\begin{array}{l}\text { Value of } \\
\text { paired } t\end{array}$ & \multicolumn{3}{|c|}{$\begin{array}{c}2.231^{*} \\
(167.22)\end{array}$} & \multicolumn{3}{|c|}{$\begin{array}{l}9.894^{\star *} \\
(2.48)\end{array}$} & \multicolumn{3}{|c|}{$\begin{array}{c}27.551^{\star \star} \\
(0.72)\end{array}$} & \multicolumn{3}{|c|}{$\begin{array}{l}6.192^{\star *} \\
(1.53)\end{array}$} \\
\hline
\end{tabular}

*indicates significant at $p<0.05$ and ** indicates significant at $p<0.01$

Figures in the parentheses are the values of standard error of mean

Source: Own calculation data from Statistical Yearbook of Bangladesh of different years

Inter regional variation in agricultural progress could also be seen from the variations in regional domestic agricultural products (RDAP) per capita. This includes variation due to agricultural productivity and landman ratio. Per capita RDAP for the country as a whole was around Tk.1250 in the early 1980s and around Tk.3443 in the early 2000 (Table 3). It increased at the rate of 8.8 percent per annum. Among regions, per capita agricultural income was higher in the hill tracts during both the periods due to low density of population. Highly significant increase of per capita regional domestic agricultural products (PRDAP) in 20 years and remarkable increase was observed in the regions 'High Ganges River floodplain', 'Lower Meghna River and Estuarine Floodplain' and 'Low Ganges River Floodplain'. Increase of share of regional domestic agricultural products was not higher in most of the regions but it was decreased in some regions.

Table 3. Progress in per capita food-grains production, GDP from agriculture and farmer's cooperative societies in different regions

\begin{tabular}{|c|c|c|c|c|c|c|c|c|c|c|c|c|}
\hline \multirow[t]{2}{*}{ Regions } & \multicolumn{3}{|c|}{$\begin{array}{c}\text { Farmers Co-operative } \\
\text { Societies } \\
(\text { No./1000 sq km) }\end{array}$} & \multicolumn{3}{|c|}{$\begin{array}{l}\text { Per capita regional } \\
\text { domestic agricultural } \\
\text { products (Tk) }\end{array}$} & \multicolumn{3}{|c|}{$\begin{array}{l}\text { Share of regional domestic } \\
\text { agriculture products (\%) }\end{array}$} & \multicolumn{3}{|c|}{$\begin{array}{l}\text { Per capita Food-grain } \\
\text { production }(\mathrm{Kg})\end{array}$} \\
\hline & \begin{tabular}{|l|}
$1980-81$ \\
\end{tabular} & 1980-81 & \begin{tabular}{|c} 
Change in \\
20 years \\
$(\%)$
\end{tabular} & $1980-81$ & 2004-05 & $\begin{array}{c}\text { Per year } \\
\text { change } \\
(\%)\end{array}$ & $1980-81$ & 2000-01 & $\begin{array}{c}\text { Change in } \\
20 \text { years } \\
(\%)\end{array}$ & \begin{tabular}{|l|}
$1980-81$ \\
\end{tabular} & 2004-05 & \begin{tabular}{|c}
$\begin{array}{c}\text { Per year } \\
\text { change } \\
(\%)\end{array}$ \\
\end{tabular} \\
\hline HPTF & 279 & 499 & 78.5 & 1515 & 5019 & 9.3 & 13.5 & 12.7 & -6.0 & 236 & 273 & 0.6 \\
\hline KFAB & 419 & 543 & 29.6 & 1310 & 5105 & 11.6 & 9.6 & 10.9 & 13.5 & 190 & 310 & 2.5 \\
\hline BJF & 329 & 716 & 117.6 & 1319 & 5001 & 11.2 & 13.9 & 14.9 & 7.2 & 221 & 246 & 0.5 \\
\hline HGRF & 333 & 469 & 40.8 & 1135 & 4883 & 13.2 & 10.1 & 12.2 & 20.8 & 152 & 218 & 1.7 \\
\hline LGRF & 275 & 494 & 79.6 & 1073 & 4421 & 12.5 & 4.7 & 5.0 & 6.4 & 95 & 171 & 3.2 \\
\hline GTF & 211 & 348 & 65.0 & 1307 & 5006 & 11.3 & 13.0 & 13.2 & 1.5 & 170 & 170 & .0 \\
\hline SBSKF & 186 & 265 & 42.5 & 1437 & 4736 & 9.2 & 7.5 & 6.8 & -9.3 & 226 & 200 & -0.5 \\
\hline MMRF & 447 & 637 & 42.5 & 1053 & 4015 & 11.3 & 6.6 & 7.0 & 6.0 & 159 & 161 & .0 \\
\hline LMREF & 174 & 241 & 38.5 & 1147 & 4986 & 13.4 & 4.0 & 4.9 & 22.5 & 188 & 115 & -1.5 \\
\hline CCPSI & 228 & 202 & -11.4 & 1181 & 3996 & 9.5 & 6.0 & 5.8 & -3.3 & 151 & 122 & -0.8 \\
\hline $\mathrm{EH}$ & 06 & 40 & * & 5698 & 6188 & 0.3 & 3.9 & 1.3 & -66.7 & 150 & 128 & -0.6 \\
\hline DHAKA & 446 & 611 & 37.0 & 779 & 1804 & 5.3 & 7.2 & 5.3 & -26.4 & 79 & 67 & -0.6 \\
\hline $\begin{array}{l}\text { Value of } \\
\text { paired } t\end{array}$ & \multicolumn{3}{|c|}{$\begin{array}{l}4.696^{\star \star} \\
(30.73)\end{array}$} & \multicolumn{3}{|c|}{$\begin{array}{l}9.418^{\star *} \\
(320.35)\end{array}$} & \multicolumn{3}{|c|}{$\begin{array}{c}00 \\
(0.39)\end{array}$} & \multicolumn{3}{|c|}{$\begin{array}{c}0.881 \\
(15.51)\end{array}$} \\
\hline
\end{tabular}

** indicates significant at $p<0.01$ and figures in the parentheses are the values of standard error of mean

Source: Own calculation data from Statistical Yearbook of Bangladesh of different years 
The progress of per capita food-grains production in some of the regions ('Karatoya Floodplain and Atrai Basin', 'High Ganges River Floodplain' and 'Low Ganges River Floodplain') was a considerable extent because of low increase of population and use of high yielding inputs (Table 3). Some of the regions showed negative increment of per capita food-grains production mainly due to increase of vast population. For example, 'Lower Meghna River and Estuarine Floodplain' region shows very low per capita food-grains production in 2004-05. This is because population was 3.82 million in 1980-81 and it had increased to 5.84 million in 2004-05 and the net cropped area reduced to 257 thousand hectares from 345 thousand hectares. The region 'Chittagong Coastal Plain and St. Martin's Coral Island' and 'Greater Dhaka' also showed negative results most probably due to increase of their vast city population. The lower value of paired t-statistic (0.881) indicates that increment of per capita regional food-grains production was not significant.

Cropping intensity is measured as the ratio of gross cropped area to the net sown area. It was worked out on an average 154 percent in 1980-83 and 177 percent in 2000-03 i.e. it was increased 23 percent in twenty years. The highest cropping intensity was observed in the region 'High Ganges River Floodplain', the second highest in the region 'Old Himalayan Piedmont Plain and Tista Floodplain' and in the region 'Middle Meghna River Floodplain' in 2000-03. The lowest cropping intensity was observed in the region 'Sylhet Basin and Surma-Kusiyara Floodplain' during same period. The highest cropping intensity was observed in the region 'Brahmaputra-Jamuna Floodplain' in 1980-83. However, the estimated figures seemed to be satisfactory in the region 'Old Himalayan Piedmont Plain and Tista Floodplain' and in the region 'Middle Meghna River Floodplain' in both the time period and the region 'High Ganges' River Floodplain' was better in 2000-03. The regions 'High Ganges River Floodplain', 'Ganges Tidal Floodplain' and 'Lower Meghna River Floodplain and Estuarine Floodplain' seemed to be the best region where highly increased cropping intensity in the last 20 years. About 67.5 percent of the total cropped area in the region 'Old Himalayan Piedmont Plain and Tista Floodplain' was brought under HYV in 2000-03, whereas, this figure was 17.6 percent in 1980-83 (Table 4 and Table 5) indicates a higher improvement of adoption of HYV in this region. Table 5 reveals that performance of 'Karatoya Floodplain and Atrai Basin' in this regard was the most satisfactory followed by 'Old Himalayan Piedmont Plain and Tista Floodplain' and 'High Ganges River Floodplain'. The percentage of area under HYV to the total cropped area among the different regions with lower being 'High Ganges River Floodplain', 'Ganges Tidal Floodplain' and 'Sylhet Basin and Surma-Kusiyara Floodplain' in 1980-83 and 'Low Ganges River Floodplain' and 'Ganges Tidal Floodplain' in 2000-03.

Table 4. Land utilization pattern in two time periods $\mathbf{1 9 8 0 - 8 3}$ and $2000-03$ in different regions

\begin{tabular}{|c|c|c|c|c|c|c|c|c|c|}
\hline \multirow[t]{2}{*}{ Region } & \multicolumn{3}{|c|}{ Net cropped area "000" ha } & \multicolumn{3}{|c|}{ Total cropped area "000" ha } & \multicolumn{3}{|c|}{ Cropping intensity (\%) } \\
\hline & $1980-83$ & $2000-03$ & $\begin{array}{c}\text { Change in } \\
20 \text { years (\%) }\end{array}$ & $1980-83$ & $2000-03$ & $\begin{array}{c}\text { Change in } 20 \\
\text { years }(\%)\end{array}$ & $1980-83$ & $2000-03$ & $\begin{array}{c}\text { Change in } 20 \\
\text { years (\%) }\end{array}$ \\
\hline HPTF & 1183 & 1112 & -6.0 & 1997 & 2117 & 6.0 & 169 & 190 & 21 \\
\hline KFAB & 973 & 964 & -1.0 & 1334 & 1628 & 22.0 & 137 & 169 & 32 \\
\hline $\mathrm{BJF}$ & 1210 & 1143 & -5.5 & 2172 & 2132 & -1.0 & 180 & 187 & 07 \\
\hline HGRF & 1135 & 953 & -17.6 & 1667 & 1883 & 13 & 147 & 198 & 51 \\
\hline LGRF & 490 & 456 & -7.0 & 762 & 830 & 8.9 & 156 & 182 & 26 \\
\hline GTF & 1189 & 1049 & -11.8 & 1606 & 1888 & 17.6 & 135 & 180 & 45 \\
\hline SBSKF & 684 & 677 & -1.0 & 1009 & 985 & -2.4 & 148 & 145 & -3 \\
\hline MMRF & 520 & 490 & -5.8 & 891 & 932 & 4.6 & 171 & 190 & 19 \\
\hline LMREF & 345 & 307 & -11.0 & 505 & 577 & 14.3 & 146 & 188 & 42 \\
\hline CCPSI & 285 & 275 & -3.5 & 450 & 494 & 9.8 & 158 & 180 & 22 \\
\hline $\mathrm{EH}$ & 72 & 92 & 27.8 & 98 & 140 & 4.3 & 136 & 152 & 16 \\
\hline DHAKA & 511 & 407 & -20.4 & 740 & 713 & -3.6 & 145 & 175 & 30 \\
\hline Bangladesh & 8586 & 8045 & -6.3 & 13246 & 14237 & 7.5 & 154 & 177 & 23 \\
\hline $\begin{array}{l}\text { Value of } \\
\text { Paired } t\end{array}$ & \multicolumn{3}{|c|}{$\begin{array}{l}3.234^{\star *} \\
(17.31)\end{array}$} & \multicolumn{3}{|c|}{$\begin{array}{l}2.722^{\star \star} \\
(33.31)\end{array}$} & \multicolumn{3}{|c|}{$\begin{array}{c}5.691^{\star *} \\
(4.51)\end{array}$} \\
\hline
\end{tabular}

** indicates significant at $p<0.01$ and figures in the parentheses are the values of standard error of mean.

Source: Own calculation data from Statistical Yearbook of Bangladesh of different years 
Table 5. Changes of area under HYV in different regions

\begin{tabular}{|c|c|c|c|c|c|c|}
\hline \multirow[t]{2}{*}{ Region } & \multicolumn{3}{|c|}{ Area under HYV (000 ha) } & \multicolumn{3}{|c|}{ Area under HYV as a \% of total cropped area } \\
\hline & 1980-1983 & $2000-2003$ & $\begin{array}{c}\text { Increase in } 20 \\
\text { years (times) }\end{array}$ & 1980-1983 & $2000-2003$ & $\begin{array}{c}\text { Increase in } 20 \\
\text { years (times) }\end{array}$ \\
\hline HPTF & 351 & 1429 & 3.0 & 17.6 & 67.5 & 49.9 \\
\hline KFAB & 249 & 1397 & 4.6 & 18.7 & 85.8 & 67.1 \\
\hline BJF & 602 & 1324 & 1.2 & 27.7 & 62.1 & 34.4 \\
\hline HGRF & 273 & 1123 & 3.1 & 16.4 & 59.6 & 43.2 \\
\hline LGRF & 150 & 235 & 0.6 & 19.7 & 28.3 & 8.6 \\
\hline GTF & 191 & 496 & 1.6 & 11.9 & 26.3 & 14.4 \\
\hline SBSKF & 140 & 408 & 1.9 & 13.9 & 41.4 & 27.5 \\
\hline MMRF & 327 & 564 & 0.7 & 36.7 & 60.5 & 23.8 \\
\hline LMREF & 200 & 238 & 0.2 & 29.6 & 41.2 & 1.6 \\
\hline CCPSI & 286 & 357 & 0.2 & 63.6 & 72.3 & 8.7 \\
\hline $\mathrm{EH}$ & 40 & 52 & 0.3 & 40.3 & 37.1 & 3.7 \\
\hline DHAKA & 179 & 346 & 0.9 & 24.2 & 48.5 & 24.3 \\
\hline Bangladesh & 2912 & 6926 & 1.4 & 22.0 & 48.6 & 26.6 \\
\hline $\begin{array}{l}\text { Value of } \\
\text { Paired } t\end{array}$ & \multicolumn{3}{|c|}{$\begin{array}{l}3.443^{\star \star} \\
(120.57)\end{array}$} & \multicolumn{3}{|c|}{$\begin{array}{c}4.462^{\star \star} \\
(5.80)\end{array}$} \\
\hline
\end{tabular}

${ }^{*}$ Area under HYV includes area of rice \& wheat only.

** indicates significant at $p<0.01$ and figures in the parentheses are the values of standard error of mean.

Source: Own calculation data from Statistical Yearbook of Bangladesh of different years

It was estimated that only 1.7 million hectares (13.1\%) cultivated area was brought under irrigation in 1980-83, whereas 4.6 million hectare (32.2\%) were brought under irrigation in 2000-03. There existed also wide variations in the percentage of total irrigated area to the gross cultivated area from one region to another. Area irrigated in thousand hectares in 1980-81 and 2003-04 and its exponential growth rates for the period 1980-81 to 2003-04 of 12 regions and allover Bangladesh were calculated and presented in Table 6. The results showed that all the growth rates were found to be significant in all the regions except 'Chittagong Coastal Plain \& St. Martin's Coral Island'. The highest growth rate was observed in region 'Low Ganges River Floodplain' followed by 'Old Himalayan Piedmont Plain and Tista Floodplain', 'Karatoya Floodplain and Atrai Basin' and 'High Ganges River Floodplain'. Regions 'High Ganges River Floodplain' and 'Low Ganges River Floodplain' were the resource of vast water bodies because of the 'Ganges River Floodplain' region and there had enough facilities of irrigation are available in the region 'Old Himalayan Piedmont Plain and Tista Floodplain' and 'Karatoya Floodplain and Atrai Basin'. The highest fertilizer consumption was observed $457.8 \mathrm{~kg} / \mathrm{ha}$ in the 'Brahmaputra-Jamuna Floodplain' whereas, the lowest consumption was observed $34.4 \mathrm{~kg} / \mathrm{ha}$ in the 'Low Ganges River Floodplain' in 198083. This result indicates a greater unevenness in the consumption of fertilizer in different regions.

Table 6. Changes of area irrigated and its exponential growth rate in different regions

\begin{tabular}{|c|c|c|c|c|c|c|c|}
\hline \multirow[t]{2}{*}{ Region } & \multirow{2}{*}{$\begin{array}{l}\text { Growth } \\
\text { rate } \\
\text { (percent) }\end{array}$} & \multicolumn{3}{|c|}{ Gross area irrigation "000" ha } & \multicolumn{3}{|c|}{ GDA \%/Area irrigated to total cropped on } \\
\hline & & $1980-83$ & $2000-03$ & $\begin{array}{c}\text { Per year } \\
\text { change (\%) }\end{array}$ & $1980-83$ & $2000-03$ & $\begin{array}{c}\text { Per year } \\
\text { change (\%) }\end{array}$ \\
\hline HPTF & $7.37^{\star \star}$ & 175 & 824 & 18.5 & 8.8 & 38.9 & 30.1 \\
\hline KFAB & $6.54^{\star \star}$ & 198 & 800 & 15.2 & 14.8 & 49.1 & 34.3 \\
\hline BJF & $3.84^{\star \star}$ & 347 & 771 & 6.1 & 16.0 & 36.2 & 20.2 \\
\hline HGRF & $6.51^{\star \star}$ & 186 & 144 & 15.0 & 11.2 & 39.5 & 28.3 \\
\hline LGRF & $9.08^{\star \star}$ & 29 & 191 & 27.9 & 3.8 & 23.0 & 19.2 \\
\hline GTF & $2.96^{\star \star}$ & 125 & 201 & 3.0 & 7.8 & 10.6 & 2.8 \\
\hline SBSKF & $1.88^{\star \star}$ & 214 & 284 & 1.6 & 21.2 & 28.8 & -2.4 \\
\hline MMRF & $3.66^{\star \star}$ & 139 & 278 & 5.0 & 15.6 & 29.8 & 14.2 \\
\hline LMREF & $2.28^{\star \star}$ & 191 & 78 & -3.0 & 37.8 & 13.5 & -24.3 \\
\hline CCPSI & 0.35 & 129 & 137 & 0.3 & 28.7 & 27.7 & -1.0 \\
\hline $\mathrm{EH}$ & $3.05^{\star \star}$ & 34 & 20 & -2.0 & 34.7 & 14.3 & -20.4 \\
\hline DHAKA & $3.71^{\star \star}$ & 120 & 252 & 5.5 & 16.2 & 35.3 & 19.1 \\
\hline Total & $4.78^{\star \star}$ & 1737 & 4580 & 8.2 & 13.1 & 32.2 & 19.1 \\
\hline
\end{tabular}

** Indicates highly significant i.e. $\mathrm{p}<0.01$.

Source: Own calculation data from Yearbook of Agricultural Statistics of Bangladesh of different years 
Table 7 shows the growth behaviour of HYV rice, at two points of time, i.e., 1980-81 and 2004-05 reveals a sharp increase in area and production of HYV rice. HYV rice occupied 21.28 percent (5421 thousand hectares) of total rice area in Bangladesh during 1980-81 and its proportion increased to 69.63 percent (17673 thousand hectares) in 2004-05. The HYV rice area and production increased at the rate of 5.13 percent and 6.26 percent per annum respectively in Bangladesh as a whole during 1980-2005. HYV rice occupied 28.47 percent (1249 thousand hectares) of total rice area in 'Brahmaputra-Jamuna Floodplain' region in 1980-81 and its proportion was increased to 74.82 percent (2939 thousand hectares) in 200405. Area cultivated and proportion of HYV rice compared to gross rice area of this region was higher than national and all other regions but growth rate was very low compared to other regions. This was because the highest geographical as well as rice area in this region and insufficient increment of inputs (irrigation and fertilizer) compared to other regions. In the hilly region, growth rate of area and production of HYV rice was highest but HYV area, production and yield rate were not enough compared to other regions. However, 'High Ganges River Floodplain' (Pubna, Kushtia and Jessore) showed much higher growth rate of area and production followed by 'Old Himalayan Piedmont Plain and Tista Floodplain' and 'Karatoya Floodplain and Atrai Basin'. 'Greater Dhaka' showed the highest growth rate of yield (metric ton per hectare). On the other hand, Noakhali and Chittagong regions showed that minimum growth rate of area and production whereas Rajshahi-Bogra region showed the lowest growth rate of HYV rice yield. Sharma et al. (1997) examined the regional variations in the spread of new agricultural technology, found a direct relationship between cultivated area and area under HYVs and a wide range of disparities in productivity was observed among different mountainous states.

Table 7. Area, production, yield and growth rate of HYV rice in different regions

\begin{tabular}{|c|c|c|c|c|c|c|c|c|c|}
\hline \multirow[t]{2}{*}{ Region } & \multicolumn{3}{|c|}{ Area (000 ha) } & \multicolumn{3}{|c|}{ Production (000 M ton) } & \multicolumn{3}{|c|}{ Yield (M ton per ha) } \\
\hline & $1980-81$ & $\begin{array}{c}2004- \\
05^{\star}\end{array}$ & $\begin{array}{l}\text { Growth } \\
\text { rate } \\
\text { (Percent) }\end{array}$ & $1980-81$ & $\begin{array}{c}2004- \\
05^{*}\end{array}$ & $\begin{array}{l}\text { Growth } \\
\text { rate } \\
\text { (percent) }\end{array}$ & $1980-81$ & $\begin{array}{c}2004- \\
05^{*}\end{array}$ & $\begin{array}{l}\text { Growth } \\
\text { rate } \\
\text { (percent) }\end{array}$ \\
\hline (1) & (2) & (3) & $(4)$ & (5) & (6) & $(7)$ & (8) & (9) & $(10)$ \\
\hline HPTF & 439 & 316 & $8.23^{\star \star}$ & 398 & 3412 & $8.99 * \star$ & 0.91 & 1.08 & $0.76^{\star \star}$ \\
\hline KFAB & 350 & 2619 & $8.35^{\star *}$ & 360 & 3355 & $8.97^{\star *}$ & 1.03 & 1.28 & 0.62 \\
\hline BJF & 1249 & 2939 & $3.84^{\star \star}$ & 1146 & 3529 & $4.76^{\star \star}$ & 0.92 & 1.20 & $0.91^{*}$ \\
\hline HGRF & 271 & 2429 & $8.47^{\star \star}$ & 246 & 3070 & $9.83^{\star \star}$ & 0.91 & 1.26 & $1.36^{\star \star}$ \\
\hline LGRF & 76 & 544 & $6.84^{\star \star}$ & 69 & 784 & $8.06^{\star *}$ & .91 & 1.44 & $1.22^{\star \star}$ \\
\hline GTF & 463 & 1330 & $5.40^{\star \star}$ & 416 & 1365 & $6.18^{\star \star}$ & 0.90 & 1.03 & $0.77^{\star \star}$ \\
\hline SBSKF & 323 & 1047 & $5.22^{\star \star}$ & 299 & 1117 & $6.55^{\star \star}$ & 0.93 & 1.07 & 1.33 \\
\hline MMRF & 585 & 1241 & $3.56^{\star \star}$ & 515 & 1522 & $5.09 * *$ & 0.88 & 1.23 & $1.54^{\star \star}$ \\
\hline LMREF & 519 & 539 & $0.67^{* \star}$ & 440 & 415 & $1.95^{\star \star}$ & 0.85 & 0.77 & $1.28^{\star \star}$ \\
\hline CCPSI & 683 & 896 & $0.85^{\star \star}$ & 667 & 988 & $1.85^{\star \star}$ & 0.98 & 1.10 & $1.00^{\star *}$ \\
\hline $\mathrm{EH}$ & 101 & 144 & $168.00^{* *}$ & 91 & 159 & $266.46^{\star \star}$ & 0.90 & 1.10 & $0.91^{\star \star}$ \\
\hline DHAKA & 362 & 783 & 3.28 *夫 & 397 & 1139 & $4.89 * *$ & 1.10 & 1.45 & $1.61^{\star \star}$ \\
\hline Overall & 5421 & 17673 & $5.13^{\star \star}$ & 5044 & 20855 & $6.26^{\star \star}$ & 0.93 & 1.18 & $1.13^{\star \star}$ \\
\hline
\end{tabular}

* Area, production and yield were available during the research period in 2004-05

** Indicates highly significant i.e. $p<0.01$.

Source: Own calculation data from Yearbook of Agricultural Statistics of Bangladesh of different years

Three years average productions and yields of rice, wheat and minor cereals, pulses and total food-grains in 1980-83 and 2000-03 of the 12 regions were calculated and are shown in Table 8 and in Table 9 respectively. The production of rice showed continuous increase over the period in all the regions. North Bengal and Greater Mymensingh were the major rice growing regions. The increase in rice production as well as yield was notable and its production and yield almost doubled in 'Karatoya Floodplain and Atrai Basin' and 'Ganges River Floodplains'. In 'Old Himalayan Piedmont Plain and Tista Floodplain', 'Middle Meghna River Floodplain' and 'Brahmaputra-Jamuna Floodplain' production of rice was increased by 84 percent, 67 percent and 64 percent respectively over the period of two decades. Chittagong and Chittagong Hill Tracts showed lower production in relation to geographical regions but it's per hectare production was higher compared to other regions.

Wheat and minor cereals were not cultivated allover the country equally. The results of production of wheat and minor cereals indicate that these crops were cultivated highly in 'Old Himalayan Piedmont Plain and Tista Floodplain' and 'High Ganges River Floodplains' and moderately in 'Brahmaputra- 
Jamuna Floodplain' and 'Middle Meghna River Floodplain'. Yield of wheat and minor cereals was not increased in all the regions over the periods. The production of pulses was increased approximately five times in 'Ganges Tidal Floodplain', four times in 'Middle Meghna River Floodplain' and three times in 'Low Ganges River Floodplain', 'Lower Meghna River and Estuarine Floodplain' and 'Greater Dhaka' over the periods of two decades. Maximum increase of yield of pulses (48 percent) was observed in 'Middle Meghna River Floodplain' and it was decreased in 'Brahmaputra-Jamuna Floodplain' and 'Chittagong Coastal Plain \& St. Martin's Coral Island' over twenty years.

Table 8. Production of major food-grains in different regions (Thousand Metric tons)

\begin{tabular}{|c|c|c|c|c|c|c|c|c|}
\hline \multirow[t]{2}{*}{ Regions } & \multicolumn{2}{|c|}{ Rice } & \multicolumn{2}{|c|}{$\begin{array}{l}\text { Wheat and minor } \\
\text { cereals }\end{array}$} & \multicolumn{2}{|c|}{ Pulses } & \multicolumn{2}{|c|}{ Food-grains } \\
\hline & $1980-83$ & $2000-03$ & $1980-83$ & $2000-03$ & $1980-83$ & $2000-03$ & $1980-83$ & $2000-03$ \\
\hline HPTF & 1916.00 & 3534.00 & 300.00 & 549.00 & 13.00 & 12.00 & 2229.00 & 4095.00 \\
\hline KFAB & 1354.00 & 3273.00 & 154.00 & 261.00 & 23.50 & 18.50 & 1231.50 & 3552.50 \\
\hline BJF & 2538.00 & 4163.00 & 84.00 & 156.00 & 20.80 & 14.00 & 2642.80 & 4333.00 \\
\hline HGRF & 1160.00 & 3072.00 & 280.00 & 418.00 & 76.80 & 88.90 & 1516.80 & 3578.90 \\
\hline LGRF & 444.00 & 975.00 & 77.00 & 92.00 & 26.70 & 68.00 & 547.70 & 1135.00 \\
\hline GTF & 1706.00 & 2666.00 & 12.00 & 21.00 & 15.20 & 75.60 & 1733.20 & 2762.60 \\
\hline SBSKF & 1185.00 & 1862.00 & 10.00 & 6.00 & 0.70 & 0.86 & 1195.70 & 1868.86 \\
\hline MMRF & 1066.00 & 1784.00 & 135.00 & 273.00 & 4.60 & 17.50 & 1205.60 & 2074.50 \\
\hline LMREF & 664.00 & 1006.00 & 1.40 & 1.30 & 6.50 & 16.40 & 671.90 & 1023.70 \\
\hline CCPSI & 802.00 & 1102.00 & 0.30 & 0.00 & 2.50 & 4.00 & 804.80 & 1106.00 \\
\hline $\mathrm{EH}$ & 104.00 & 152.00 & 0.20 & 0.00 & 0.30 & 0.60 & 104.50 & 152.60 \\
\hline DHAKA & 818.00 & 1274.00 & 55.00 & 75.00 & 11.80 & 34.30 & 884.80 & 1383.30 \\
\hline
\end{tabular}

Source: Own calculation data from Yearbook of Agricultural Statistics of Bangladesh of different years

The remarkable increase (more than 100 percent) of total food-grains production in two decades was observed in 'Old Himalayan Piedmont Plain and Tista Floodplain', 'Karatoya Floodplain and Atrai Basin', 'Low Ganges River Floodplains' and 'High Ganges River Floodplains'. In other regions, food-grains production was increased over 50 percent over the period. In the first five regions (Table 9), the yield almost doubled over the period of two decades as against approximately 50 percent in other regions. This increasing trend of production and yield of food-grains occurred because of new high production techniques over the period. But net cropped area was decreased 6.3 percent and total cropped area was increased only 7.5 percent in the country as a whole over the period. Thomas (1980) showed that considerable amount of regional variation between four divisions existed both in per capita production of food-grains and per capita availability of food-grains and the variations in the district level was more pronounced.

Table 9. Yield of major food-grains in different regions (Metric tons per hectare)

\begin{tabular}{|c|c|c|c|c|c|c|c|c|}
\hline \multirow[t]{2}{*}{ Regions } & \multicolumn{2}{|c|}{ Rice } & \multicolumn{2}{|c|}{$\begin{array}{l}\text { Wheat and minor } \\
\text { cereals }\end{array}$} & \multicolumn{2}{|c|}{ Pulses } & \multicolumn{2}{|c|}{ Food-grains } \\
\hline & $1980-83$ & $2000-03$ & $1980-83$ & $2000-03$ & $1980-83$ & $2000-03$ & $1980-83$ & $2000-03$ \\
\hline HPTF & 0.52 & 0.93 & 1.79 & 2.25 & 0.71 & 0.73 & 0.57 & 1.01 \\
\hline KFAB & 0.53 & 1.04 & 1.86 & 2.21 & 0.67 & 0.68 & 0.58 & 1.08 \\
\hline BJF & 0.57 & 0.99 & 2.15 & 1.77 & 0.78 & 0.71 & 0.58 & 1.01 \\
\hline HGRF & 0.43 & 1.04 & 1.89 & 2.14 & 0.72 & 0.83 & 0.51 & 1.10 \\
\hline LGRF & 0.35 & 0.79 & 1.79 & 1.56 & 0.59 & 0.80 & 0.40 & 0.82 \\
\hline GTF & 1.20 & 1.79 & 1.50 & 1.91 & 0.56 & 0.71 & 1.19 & 1.72 \\
\hline SBSKF & 1.30 & 2.13 & 2.00 & 2.00 & 0.64 & 0.75 & 1.30 & 2.13 \\
\hline MMRF & 1.58 & 2.48 & 1.67 & 1.66 & 0.61 & 0.90 & 1.58 & 2.30 \\
\hline LMREF & 1.40 & 2.11 & 1.40 & 1.30 & 0.51 & 0.64 & 1.37 & 2.03 \\
\hline CCPSI & 1.98 & 2.60 & 1.50 & 0.00 & 0.76 & 0.56 & 1.97 & 2.56 \\
\hline $\mathrm{EH}$ & 1.60 & 2.30 & 2.00 & 0.00 & 0.60 & 0.75 & 1.59 & 2.28 \\
\hline DHAKA & 1.49 & 2.66 & 1.96 & 1.74 & 0.58 & 0.75 & 1.48 & 2.44 \\
\hline
\end{tabular}

Source: Own calculation data from Yearbook of Agricultural Statistics of Bangladesh of different years 
Data on most of the indicators reflect an improvement in the use of modern agricultural inputs and other indicators over the past two decades. Average percentage of net cropped area to total geographic area decreased from 60.8 in 1980-83 to 56.1 in 2000-03, while the average cropping intensity increased from 150 percent in 1980-83 to 178 percent in 2000-03 (Table 10). Average area under high yielding variety as a percentage of total cropped area increased from 26.7 percent to 52.6 percent i.e. doubled in 20 years, while average percentage of area irrigated to total cropped area increased from 18 percent to 29 percent i.e. 1.6 times over two decades. Average consumption of chemical fertilizer increased from 109 $\mathrm{kg} / \mathrm{ha}$ to $171 \mathrm{~kg} / \mathrm{ha}$ in 20 years and average food-grains productivity increased from 124 to 323 metric ton per 100 ha. In general, the disparity got declined in case of most of the indicators over the two decades. Region-wise increase of the value of these indicators is shown in Table 10.

Table 10. Values of different development indicators of crop sector according to regions

\begin{tabular}{|c|c|c|c|c|c|c|c|c|c|c|c|c|c|c|}
\hline \multirow[t]{2}{*}{ Regions } & \multicolumn{7}{|c|}{$1980-83$} & \multicolumn{7}{|c|}{ 2000-03 } \\
\hline & NCAGA & $\mathrm{Cl}$ & AHYGCA & AIGCA & FCKH & FPMT & NCAAW & NCAGA & $\mathrm{Cl}$ & AHYGCA & AIGCA & FCKH & FPMT & NCAAW \\
\hline HPTF & 73.2 & 139 & 17.6 & 8.8 & 57 & 109 & 177 & 68.1 & 190 & 67.5 & 38.9 & 101 & 254 & 37.2 \\
\hline KFAB & 72.9 & 137 & 18.7 & 14.8 & 58 & 117 & 393 & 72.3 & 169 & 85.8 & 49.1 & 108 & 276 & 40.1 \\
\hline BJF & 73.7 & 180 & 27.7 & 16.0 & 58 & 112 & 459 & 68.6 & 187 & 62.1 & 36.2 & 101 & 287 & 33.0 \\
\hline HGRF & 77.0 & 147 & 16.4 & 11.2 & 51 & 109 & 339 & 63.8 & 198 & 59.6 & 39.5 & 110 & 319 & 40.7 \\
\hline LGRF & 71.2 & 156 & 19.7 & 3.8 & 40 & 124 & 34 & 65.0 & 182 & 28.3 & 23.0 & 82 & 369 & 40.0 \\
\hline GTF & 50.5 & 135 & 11.9 & 7.8 & 119 & 111 & 109 & 61.1 & 180 & 26.3 & 10.6 & 172 & 300 & 49.9 \\
\hline SBSKF & 53.8 & 148 & 13.9 & 21.2 & 130 & 112 & 40 & 53.7 & 145 & 41.4 & 28.8 & 213 & 319 & 36.1 \\
\hline MMRF & 78.8 & 171 & 36.7 & 15.6 & 158 & 130 & 231 & 72.9 & 190 & 60.5 & 29.8 & 230 & 367 & 42.6 \\
\hline LMREF & 63.2 & 146 & 29.6 & 37.8 & 137 & 106 & 89 & 51.3 & 188 & 41.2 & 13.5 & 203 & 331 & 47.8 \\
\hline CCPSI & 38.2 & 158 & 63.6 & 28.7 & 197 & 130 & 222 & 35.3 & 180 & 72.3 & 27.7 & 256 & 373 & 42.1 \\
\hline $\mathrm{EH}$ & 8.3 & 136 & 40.3 & 34.7 & 159 & 178 & 63 & 6.9 & 152 & 37.1 & 14.3 & 228 & 259 & 30.8 \\
\hline DHAKA & 68.4 & 145 & 24.2 & 16.2 & 148 & 151 & 173 & 54.7 & 175 & 48.5 & 35.3 & 244 & 422 & 44.8 \\
\hline Mean & 60.8 & 150 & 26.7 & 18.0 & 109 & 124 & 194 & 56.1 & 178 & 52.6 & 28.9 & 170.7 & 323 & 40.4 \\
\hline
\end{tabular}

Source: Own calculation data from Yearbook of Agricultural Statistics of Bangladesh of different years

The disparities among the regions as measured by mean and CV of the seven indicators described in Table 10 and is shown in Table 11 according to value and rank order. 'Brahmaputra-Jamuna Floodplain' was the first position in 1980-83 whereas 'Chittagong Coastal Plain and St. Martin's Coral Island' was in 2000-03 based on mean. Similarly, 'Chittagong Coastal Plain and St. Martin's Coral Island' was the second position in 1980-83 whereas 'Middle Meghna River Floodplain' was in 2000-03. 'Lower Meghna River and Estuarine Floodplain' and 'Greater Dhaka' were in the first and second positions respectively based on the variability (CV) of the development indicators in 1980-83 whereas 'Karatoya Floodplain and Atrai Basin' and 'Old Himalayan Piedmont Plain and Tista Floodplain' were in the first and second position respectively in 2000-03. The overall results indicate that 'Sylhet Basin and Surma-Kusiyara Floodplain', Greater Dhaka', 'Middle Meghna River Floodplain' and 'Lower Meghna River and Estuarine Floodplain' regions has improved remarkably in the last twenty years.

Table 11. Regional disparities based on crop sector's development indicators

\begin{tabular}{|c|c|c|c|c|c|c|c|c|}
\hline \multirow[t]{3}{*}{ Regions } & \multicolumn{4}{|c|}{ 1980-83 } & \multicolumn{4}{|c|}{ 2000-03 } \\
\hline & \multicolumn{2}{|c|}{ Mean } & \multicolumn{2}{|c|}{ C.V. } & \multicolumn{2}{|c|}{ Mean } & \multicolumn{2}{|c|}{ C.V. } \\
\hline & Value & Rank & Value & Rank & Value & Rank & Value & Rank \\
\hline HPTF & 83.03 & 9 & 74.85 & 7 & 108.10 & 11 & 76.57 & 2 \\
\hline KFAB & 115.91 & 4 & 112.54 & 11 & 114.33 & 7 & 72.75 & 1 \\
\hline BJF & 132.24 & 1 & 116.68 & 12 & 110.70 & 10 & 84.67 & 3 \\
\hline HGRF & 107.17 & 5 & 105.65 & 10 & 118.66 & 6 & 87.95 & 4 \\
\hline LGRF & 64.10 & 12 & 88.82 & 9 & 112.76 & 9 & 111.10 & 12 \\
\hline GTF & 77.74 & 10 & 68.54 & 5 & 114.27 & 8 & 92.89 & 6 \\
\hline SBSKF & 74.13 & 11 & 73.93 & 6 & 119.57 & 5 & 93.38 & 7 \\
\hline MMRF & 117.30 & 3 & 65.99 & 4 & 141.83 & 2 & 88.51 & 5 \\
\hline LMREF & 86.94 & 8 & 52.77 & 1 & 125.11 & 4 & 94.20 & 8 \\
\hline CCPSI & 119.64 & 2 & 64.82 & 3 & 140.91 & 3 & 94.81 & 9 \\
\hline $\mathrm{EH}$ & 88.47 & 7 & 76.57 & 7 & 104.01 & 12 & 103.11 & 11 \\
\hline DHAKA & 103.69 & 6 & 63.40 & 2 & 146.33 & 1 & 99.41 & 10 \\
\hline
\end{tabular}

Mean values of indicators were ranked according to descending order of magnitude and CVs were ranked according to ascending order of magnitude.

Source: Own estimation 


\section{Conclusion}

The study was designed to examine the economic progress and regional variations of crop production in Bangladesh. 'Ganges Tidal Floodplain' for rural literacy rate, 'Karatorya Floodplain and Atrai Basin' for ratio of agricultural workers and per capita food-grains production and 'Brahmaputra-Jamuna Floodplain' for number of co-operative societies and share of regional domestic agricultural products were the best regions in the recent years. It means that socioeconomic progress was occurred in different regions in the last 20 years. 'Middle Meghna River Floodplain' and 'High Ganges River Floodplain' had the highest and second highest yield growth rate of HYV rice respectively whereas 'Chittagong Coastal Plain and St. Martin's Coral Island' and 'Greater Dhaka' had the highest and second highest yield of food-grains respectively. The findings also reveal that 'Old Himalayan Piedmont Plain and Tista Floodplain', 'Karatoya Floodplain and Atrai Basin', 'Brahmaputra- Jamuna Floodplain', 'Middle Meghna River Floodplain' and 'Chittagong Coastal Plain and St. Martin's Coral Island' are the high developed regions in Bangladesh.

The process of agricultural development in the 'Low Ganges River Floodplain', 'Lower Meghna River and Estuarine Floodplain' and 'Eastern Hills', as the study reveals, is slow and unbalanced over the space. These regions require improvement of various dimensions for enhancing their levels of development. Thus, there is a need for taking some immediate steps to put a check in this unbalanced and lop-sided growth of the regional economy and should be given special priority to bridge-up the immense development by the proper agricultural policy. The factors should be identified that are responsible to influence the variations of crop sector's growth in different regions for the improvement in agricultural growth. The imbalances between the regions should be measured to formulate the strategies for balanced agricultural development in depressed regions.

\section{Acknowledgement}

The author sincerely acknowledges the financial grant offered by Bangladesh University Grant Commission (UGC) in carrying out the research project.

\section{References}

Ahmed, A.R., Bhuiya, A.A., Reza, Z.A. and Hossain, M.Z. 2004. Methods of Statistics, S. Ahmed and Associates, 276pp.

BBS, 1996. Agriculture Census. The Bangladesh Census of Agriculture and Livestock, Bangladesh Bureau of Statistics, Ministry of Planning, Government of the People's Republic of Bangladesh.

Quddus, M.A., Sen, K. and Salimullah, M. 2004. Performance of crop production in Bangladesh: Growth and regional disparities. Bangladesh Journal of Agricultural Economics, 27(2): 57-74.

Sharma, R.K., Bala, B. and Sharma, H.R. 1997. Regional disparities in agricultural development - A study of mountainous states. Indian J. of Agricultural Economics, 52 (3): 394-405.

Singh, V. 1990. Regional Disparities in Agricultural Development, Deep and Deep Publications, New Delhi, India, 13pp.

Thomas, V. 1980. Regional differences in foodgrain production and distribution in Bangladesh. The Bangladesh Development Studies, 8(4): 94-105. 